\title{
Russian and Siberian-Tatar language contacts in middle of XX century
}

\author{
Anna Isakova* \\ Tyumen state university, Tyumen, Russia
}

\begin{abstract}
This article is devoted to the language contacts between the Siberian Tatars and the Russians in the XX century. We have executed a research of the Russian borrowed lexicon in the dictionary of dialects of the Siberian Tatars, written by D.G. Tumasheva in 1992. 93 borrowed lexemes from Russian and Western European languages relating mainly to the household sphere of language functioning of the Siberian Tatars have been revealed. We assume that there were Russian loanwords in the language of the Siberian Tatars in the third period of the development of the Tatar people's spoken language, namely in the 40-60s of the XX century. The author revealed several borrowed lexemes from the dictionary of dialects of the Siberian Tatars, pertaining to the household lexicon of the language of the Siberian Tatars. The direct permanent intense and stable contacts between the Russian and Tatar unrelated languages led to the emergence of broad and thematically diverse formation of Russian loanwords in the Tatar language. The household sphere of functioning of the Siberian Tatar language is less susceptible to intrusion of foreign vocabulary. Thus, in order to analyze its structural and semantic development, there was an attempt to analyze the identified borrowing according to two corpuses of the Tatar language, namely to identify the right words and confirm the use of the language, as well as to determine the frequency of their usage. According to the Tatar National Corpus "Tugantel" and the Corpus of written Tatar, the most frequent borrowings are estəl (TNC - 4682, CWT-16155), kөpkə (TNC -1242, CWT - 9547), Torba (TNC -206, CWT1141).
\end{abstract}

\section{Introduction}

The problem of languages interaction and linguistic contacts remains within the field of view of the community of linguistic science. It has not only preserved its relevance, but is also continuing to provide new data for the study. The first researchers of contacts were U. Weinreich, H. Schuchardt, E. Haugen, D. Greenberg, S. Irwin, B. Rosenzweig, L. Szczerba and others. Language contact issues are explored in modern linguistics at the works of N. D. Arutyunova, S. G. Vorkachev, V. I. Karasik, V. A. Maslova, Yu. Stepanov, V. N. Telia and others. Modern research in the field of language contacts, as rightly argues T. S. Artamonova, aimed at studying the linguistic identity and language of exchange. There are no currently established definitions and a clear distinction of concepts relating to language contacts (bilingualism, borrowing and interference, the confusion of languages and etc). There are different points of view on the conditions and characteristics of appearance, performance, and the consequences of contact languages. Following the publication of the article "Language contact" by E. Haugen, the term "language contact" was introduced into scientific circulation. In our research, we define language contacts according to T. V. Zherebilo as "the interaction of two or more languages in the process of communicating linguistic groups who have economic, cultural and political relations, the results of which are linguistic borrowing, interference phenomena, the confusion of languages, different types of bilingualism, language change. Language borrowing is the process and the result of transition of words, grammar, morpheme, phoneme from one language to another, which is the most common form of contacts" [1].

\section{Language contacts: statement of the problem}

Language contacts are categorized by intensity, character, stability and duration, etc. [2: 190]. There is direct and indirect, casual and permanent interaction of unrelated, closely related, related languages with different grammatical structures.

Interaction of languages leads to the interaction of cultures conditioned by non-identity of two languages, comparison of one's own and foreign through its comprehension of others, mutual concession and extension of the cultural space in their respective contact zones [3]. The result of the interaction of language is lexical borrowings, which have, as a rule, the following features: semantic exploration, frequency of use, phonetic and morphological adaptation of foreign language words, the correlation of borrowed words with grammatical and lexical categories, grammatical classes, the language of the recipient [2: 191].

The issues of studying the interaction of the Russian and Tatar languages engaged G. H. Ahatov, E. M. Ahunzyanov, M. Z. Zakiev, A. Sh. Yusupova, Kh. Ch. Alishina, G. Ch. Utyasheva, T. E. Grigorieva and others.

* Corresponding author: annatelem@gmail.com 


\section{Features of language contacts of the Russians and Siberian Tatars}

"Siberia before the arrival of Russian settlers represented a heterogeneous ethnically territory whose population was formed over thousands of years, with a single geographical environment and the same economic activity. It has led to the fact that many indigenous peoples of Siberia has developed a set of elements, ethnicity, are unlikely can now set" [4]. After joining Siberia to Russia in 1586, language contacts of the Russians and the Tatars are characterized by geographical proximity, historical and political proximity, economic interaction, certain distancing in the domestic sphere. The direct permanent intense and stable contact of unrelated the Russian and Tatar languages led to the emergence of broad and thematically diverse formation Russian loanwords in the Tatar language in the following historical periods:

1. beginning of the XVII - the appearance of large settlements - Yar, Tatar Singul, Memorial, Khokhlovo, Petelino, Osinovo, Aslan, Avazbakeevo, Novoatyalovo, Ivanovka;

2. XVII-XVIII- increase in population due to the flow of immigrants, dissenters from the central regions of Russia;

3. XIX- settling steppe zone;

4. the second half of the XIX - early XX - appearance of more than 300 settlements [4].

\section{Russian borrowings in the language of the Siberian Tatars}

In our study, we consider the Russian loanwords in the language of the Siberian Tatars in the third period of the development of the Tatar people's spoken language, namely the 40-60s of the XX century. This period includes the military and post-war period, characterized by a specific national language policy (the transition of many national schools of the Russian-language form of training, etc.), the national consolidation of the Siberian Tatars, a high rate of urbanization. The study period of state language policy, aimed at "creating nationless society in which nations and national languages right is governed by administrative rules [5: 37] and the high rate of urbanization led to the linguistic nihilism, which means national assimilation and consequent loss of national language skills. According to periodization of D. M. Iskhakov, studied vocabulary refers to the period of national consolidation of Siberian Tatars, in which there is convergence of the ethnic Tatars, the Siberian Tatars from the Volga-Ural region due to the different ethnic, demographic and ethno-cultural processes. One reason for the active reduction of national schools is given a secondary role, in which, according to D.Z. Shamsutdinov, it is "a landmark step in the transition of non-Russian students in the Russian-language form of communication". Beginning of the third period of development of the Tatar people's spoken language is characterized by "a very strong influence of unilateral Tatar-Russian bilingualism. It appears and gets a certain distribution of the mixed Russian-language version of the conversation, which can not but have some influence on the literary norm [5: 29]. Firmly established literary norms of the Tatar language allows one to restrain the flow of loanwords in the language of the Siberian Tatars and prevent confusion in the language of international communication.

Exploring the borrowing of archive documents and dictionaries Siberian Tatars demonstrates "that often borrowed not only the tokens, but word-forming suffixes" [6]. The process of borrowing is not only direct; contact languages can sometimes act as intermediaries for the translation of borrowings from other languages. "As a result of inter-ethnic contacts of nationalities living in the territory of Western Siberia, and in particular in Tobolsk, there is enrichment and vocabulary borrowed lexemes that are firmly established in the lexicon of the Russian and Tatar peoples" [6: 50]. "Foreign words, penetrating into the dialect of the Tatar language system, are gradually assimilated; removed foreign-language features sound like design words. Its reflection has such features in Tatar vocalism as a vowel harmony phenomenon, labial influence of back vowels top lift, various exchange consonant" [7].

\section{Russian borrowings in the dictionary of dialects of the Siberian Tatars}

The first dictionary of the Siberian Tatars is "words radical, the most necessary note for training in the Tatar language, collected at Tobolsk main school by the teacher of the Tatar language, St. Sophia Cathedral priest Iosif Giganov and Yurt mullahs were testified". It was published in 1801 as an annex to the grammar of the Tatar language. Turkologist J. Giganov recorded large lexical material of local dialects of the Siberian Tatars and placed it in the thematic groups. "Words are placed in three columns: the first - Tatar typed in Arabic script; second - in accordance with the orthoepy laws, Russian letters were given for Tatar words, in the third - the Russians" [8: 30]. The dictionary contains 1700 words, among which there are only 14 borrowings from the Russian language. "Dictionary of dialects of the Siberian Tatars", compiled by the Academician of Tatarstan, D. G. Tumasheva, continuing the tradition of J. Giganov, was published in Kazan at 1992. Dilara Garifovna developed a functional-semantic method in the grammar of the Tatar language, and offered to substantiate the concept that the dialects of the Siberian Tatars historically go back to the languages and dialects belonging to different ethnic collectives of the Western Siberians. The majority of vocabulary of the dictionary was collected by D. G. Tumasheva during 20 years of field expeditions. This also includes the vocabulary of the "examples of folk literature of Turkic tribes" by V. Radlov, dictionaries of J. Giganov, L. Budagov, L. V. Dmitriev, M. A. Abdurakhmanov, G. H. Ahatov. The dictionary does not include general vocabulary of the Tatar literary language. "Lexical data, which are collected by Dilara Garifovna, help solve a number of complex issues related to migration routes and language 
contacts of the Siberian Tatars" [4: 13]. In 1977 D. G. Tumasheva identified three dialects in the dialects of the Siberian Tatars living in Tyumen, Omsk, Novosibirsk, Tomsk and Kemerovo regions,: Tobol and Irtysh (with Tyumen, Tobolsk, Tevrizsky (kurdakskim), Tarski and Zabolotny), Barabinsk and Tomsk (with eushtinochatskim, kalmakskim dialects and Orsk). Dictionary dialects of the Siberian Tatars is "the result of forty years of hard work of Dilara Garifovna Tumasheva [4: 10].

We revealed borrowed lexemes from the dictionary of dialects of the Siberian Tatars, pertaining to the household lexicon of the language of the Siberian Tatars: МИНАСЙӘ, ЫСТА̀Н, ПУТПАЛ, КӘТКӘ, КОРОМИСЛО, ПИНКӘ, ЫСНАેС, УПШӸ, МУЛАТУ̀К, ШЫФАНИР, КАРТАПКА, КҮКФИРАС, КУЛӘСӘे, ПИСУР, МАЗИЛКА, МУНАСӸ, ОСТОГАН, УСТУГАН, ӨСТӘЛ, БАЛАС, ПАЛАТПАШ, МАНАेР, ПАРАНАે, ПАРАСА̀, ПУТПАЛ, ПҮКЕРӘेП, БОГРӘेП, БУРАНАે, ПИСУР, ТОРУТТИН, УПШЫР, ҮСЛӘҮЦӘРӘТ, ЦӘЙГҮН, ЦИШНӘК, ЫСМУЛЛА, ЫШТАНБУӸ, ЕРЕТНЕК etc.

\section{Russian loanwords in the corpuses of the Tatar language}

The household sphere of functioning of the language of the Siberian Tatars is less susceptible to intrusion of foreign vocabulary. So in order to analyze its structural and semantic development, there was an attempt to analyze the identified borrowing according to corpuses of the Tatar language, namely to identify the right words and confirm the use of the language, as well as to determine the frequency of their usage.

The corpus of the written Tatar (CWT) is a collection of electronic texts in the Tatar language, in most cases related to publics, fiction and scientific literature in the humanities. In 2010, a research fellow of the Institute of Computer Science Academy of Sciences of the Republic of Tajikistan, Doctor Sayhunov M.R., Associate Professor of the department of Applied Linguistics at Kazan Federal University, Ibragimov T.I. and Khusainov R.R., an engineer of company "GDC" started to create a written corpus. At present, the corpus includes more than 116 million words.

Tatar National Corpus "Tugantel" (hereinafter TNC) is a linguistic resource for the modern literary Tatar language. There are more than 26 million words in usage, texts of various genres. Also it has morphological markings. The developers of the project are staff of the Research Institute "Applied Semiotics" at Tatarstan Academy, Kazan Federal University and the HSE.

According to the corpuses, the most frequent borrowings are өстәл (TNC-4682, CWT-14,642), көпкә (TNC-1242, CWT-9547), торба (TNC-206, CWT1141). The authors also noted the use of words күләсә (TNK-4, CWT-8) писур (TNK-4,CWT-6), манар (TNK-3, CWT-6), бурана (TNC-1, CWT -2), мелек (TNC-1, CWT-2), мийец (TNC-2, CWT-0), баструк (TNK-2, CWT-0), кәләгә (TNC-1, CWT-0), кәткә (TNC-1, CWT-0), ыстан (TNC-0,CWT-41).
Typologically the Russian and Tatar languages are not the same: Tatar is an agglutinative language, Russian is inflected, wherein there is frequent use of synthetic means. The prosodic system of the contact languages differs by setting stress: in the Tatar language, as a rule, fixed single lax is emphasized, which falls on the last syllable (except for exceptions and borrowings). In Russian there is moving stress, which can be moved to a different syllable. G.Ch. Utyasheva, researching the Russian loanwords in Tobol and Irtysh dialect of the Tatar language, notes that "some of the stress in borrowing falls on the last syllable, which in other cases does not change" [9]. It corresponds to the stress in the source language. G. H. Akhatov wrote, "The Western Siberian Tatars put the accent in words, borrowed from the Russian language, on the first syllable" [9: 15]. In this study, the emphasis in most borrowed lexems (набула̀т, палатпа̀ш, мүцкә̀, мана̀р, парана̀, параса̀, богрәेп, бурана̀ and etc.) falls on the last syllable, following the traditions of the Tatar language prosodic system.

\section{Conclusion}

The study of the vocabulary is thematically related to the domestic sphere of language functioning. The absence of most of the words in the corpus of written Tatar and the Tatar National Corpus "Tugantel" is not clearly a sign of the absence in the language of the Siberian Tatars. Some borrowed lexemes (bichir - kichə, etc.) have been superseded by the Tatar literary language, i.e., there was a process of internal borrowings. Some lexemes assimilated under the influence of phonetic rules of the Siberian Tatar language and changed graphically.

The reported study was funded by RFBR according to research project № 18-312-00002.

\section{References}

1. T.V. Zherebilo, Glossary of linguistic terms. Ed. 5th, corr. and ext (Nazran: OOO "Pilgrim", 2010)

2. L.F. Barannik, Interlanguage contacts dialect level (based on the vocabulary of Russian resettlement dialects of the south of Ukraine). (2006)

3. L.P. Dronov, Bulletin of the Tomsk State University 277 (2003)

4. Kh.Ch. Alishina, Proceedings of Slovtsovskie reading XVIII All-Russian Scientific Studies Conference, 147-149 (2006)

5. M.Z. Zakiev, Tatar grammar (T. I. Phonetics, 1995)

6. O.N. Gauch, G.Ch. Fayzullina, Literature and Culture 4(42), 45-52. (2015)

7. Kh.Ch. Alishina, Dialects of Siberian Tatars of the south of the Tyumen region. Abstract of the thesis for the degree of kand.filol.nauk (Kazan, 1992)

8. A.Sh. Yusupova, Literature and Culture, 2 (2012) 
9. G.Ch. Utyasheva, Russian loanwords in the Tobol and Irtysh dialect of the Siberian Tatars, the dissertation of the candidate of philological sciences (Tobolsk, 2006)

\section{Sources}

1. J. Giganov, The root words, it is necessary to note for learning the Tatar language, collected in Tobolsk by primary school teacher of the Tatar language, St. Sophia Cathedral and priest Joseph Giganov and Yurt mullahs good report SPb (Publishing House of the Academy of Sciences, 1801)

2. D.G. Tumasheva, Dictionary of the dialects of Siberian Tatars (Publishing House of Kazan University, 1992)

3. Corpus of Written Tatar http://corpus.tatar/

4. Tatar National Corpus "Tugantel" http://webcorpora.net/TatarCorpus/search/?interface_language $=\mathrm{ru}$ 